\title{
Snus under svangerskap er ikke ufarlig
}

\author{
Bruk av snus kan ikke anbefales som et alternativ til røyking for svangre kvinner som sliter med \\ å slutte å røyke.
}

Publisert først på nett 27.3. 2012

Engelsk oversettelse på www.tidsskriftet.no

Røyking i svangerskapet øker risikoen for en rekke graviditetskomplikasjoner. Snusbruken blant unge kvinner i Norge har økt samtidig som færre røyker. Kan snus anbefales svangre kvinner som et alternativ til røyking?

Snus er helseskadelig, vedlikeholder og forsterker avhengighet og har ikke vitenskapelig dokumentert effekt som røykeavvenningsmiddel. En svensk oversiktsartikkel publisert i Läkartidningen i 2011 (1) viser at snus under graviditet er mer skadelig enn vi trodde. Vi har derfor gjennomgått de tre hovedstudiene som er referert i artikkelen, som alle er basert på data fra det svenske medisinske fødselsregisteret.

Allerede i 2003 kom den første svenske oppfølgingsstudien med mer enn 23000 kvinner som enten brukte snus, røykte eller ikke brukte tobakk (2). Den viste at snusing økte risikoen for prematur fødsel og svangerskapsforgiftning. For tidlig fødsel var nesten dobbelt så vanlig hos snusere som hos dem som ikke brukte tobakk. I 2010 kom to studier fra samme svenske forskningsgruppe $(3,4)$ som bekreftet funnet om $ø \mathrm{kt}$ risiko for prematur fødsel. I tillegg viste de at snusing er assosiert med økt risiko for dødfødsel. Man fant også at barn av snusere veide gjennomsnittlig $39 \mathrm{~g}$ mindre enn barn av kvinner som ikke brukte tobakk. En fersk studie fra 2011 viste at snusing økte risikoen for apné hos nyfødte (5). snusbrukerne og kvinnene som verken brukte snus eller røykte.

På den annen side: Det er metodisk best å spørre om snusbruk tidlig i svangerskapet hvis man kun skal spørre én gang. Enda bedre hadde det vært å analysere bare dem som med sikkerhet har brukt snus gjennom hele svangerskapet. Det er sannsynlig at de registrerte skadevirkningene da hadde vært større enn det studiene viste. Antakelig er det med snusing som med røyking: Hvis man ikke slutter når svangerskapet er erkjennes, så gjør man det ikke. Røykeavvenningstilstak ved første ultralydundersøkelse er for sent.

Vi anser de svenske studiene som så metodisk gode at man må kunne advare om at snusing i svangerskapet gir økt risiko for dødfødsel og for tidlig fødsel og at det kan påvirke fødselsvekten i negativ retning.

\section{Snus i svangerskapet frarådes}

Alle kvinner må få informasjon om at bruk av snus under svangerskapet medfører en risiko som likner risikoen ved røyking. Vi mener det ikke er forsvarlig å anbefale gravide å bruke snus som røykeerstatning.

Det er ikke gjort mange studier om bruk av nikotinerstatning under svangerskapet (6-8). Man vet derfor lite om effekt og sikkerhet ved bruk av slike preparater i denne tiden. Vi mener likevel at nikotinerstatning

\section{«Det hviler et særlig ansvar på dem som anbefaler bruk av et produkt som kan forårsake skadevirkninger»}

alene er å foretrekke fremfor røyking og snusing for dem som absolutt ikke klarer å slutte med nikotin. Nikotindosen for fosteret ved vanlig bruk av nikotinerstatning antas å være lavere enn den vil være ved bruk av snus. Dessuten inneholder snus og tobakksrøyk flere andre giftige og skadelige stoffer. Hvis nikotinavhengighet er problemet, vil den mest oversiktlige løsningen være rådgivning sammen med nikotinerstatning, som ikke har tobakkens innhold av karsinogener og andre giftstoffer. Men kvinnene må opplyses om mulige skadevirkninger på kort og på lang sikt og om at effektene ved bruk av nikotinerstatning i svangerskapet er dårlig kartlagt.

Det hviler et særlig ansvar på dem som anbefaler bruk av et produkt som kan forårsake skadevirkninger. I svangerskapsomsorgen bør det legges sterk vekt på motivasjonsbehandling og tett oppfølging for røykeslutt og snuseslutt - og nikotinerstatning må være siste utvei. De fleste gravide vil være motivert for å unngå tobakksbruk dersom de blir informert grundig om mulige konsekvenser. Jordmødre og fastleger har her en viktig oppgave.

\section{Maja-Lisa Løchen \\ maja-lisa.lochen@uit.no \\ Institutt for samfunnsmedisin \\ Universitetet i Troms $\emptyset$ \\ Svein Høegh Henrichsen \\ Langbølgen legesenter, Oslo \\ Tom K. Grimsrud \\ Kreftregisteret}

\section{Turid Lingaas Holmen}

Institutt for samfunnsmedisin

Norges teknisk-naturvitenskapelige universitet

\section{Frode Gallefoss}

Lungeseksjonen

Sørlandet sykehus, Kristiansand

Maja-Lisa Løchen (f. 1954) er dr.med. og spesialist i hjertemedisin. Hun er professor i forebyggende medisin ved Universitetet i Troms $\varnothing$ og overlege ved Hjertemedisinsk avdeling, Universitetssykehuset Nord-Norge.

Forfatter har fylt ut ICMJE-skjemaet og oppgir ingen interessekonflikter.

Svein Høegh Henrichsen (f. 1952) er spesialist i allmennmedisin, fastlege ved Langbølgen legesenter i Oslo og leder Norsk forening for allmennmedisins referansegruppe for astma og kols. Han arbeider nå som seniorrådgiver i avdeling allmennhelsetjeneste i Helsedirektoratet.

Forfatter har fylt ut ICMJE-skjemaet og oppgir ingen interessekonflikter.

Tom Kristian Grimsrud (f. 1955) er dr.med. og spesialist i arbeidsmedisin. Han er forsker/ epidemiolog innen yrkes- og miljørelatert kreft ved Kreftregisterets forskningsavdeling, Oslo. Forfatter har fylt ut ICMJE-skjemaet og oppgir følgende interessekonflikter: Grimsrud var medlem av Tobakksskaderådet i 2011 og har fått betalt for møtedeltakelse. ble spurt om tobakksbruk tidlig i svangerskapet, slik at de som sluttet eller startet å røyke senere, ikke ble registrert, har antakelig redusert forskjellene mellom 
Turid Lingaas Holmen (f. 1947) er dr.med., spesialist i pediatri og professor i ungdomsmedisin og epidemiologi ved HUNT forskningssenter, Institutt for samfunnsmedisin, Norges teknisk-naturvitenskapelige universitet.

Forfatter har fylt ut ICMJE-skjemaet og oppgir ingen interessekonflikter.

Frode Gallefoss (f. 1956) er spesialist $i$ indremedisin og i lungemedisin. Han er overlege ved Lungeseksjonen, Sørlandet Sykehus Kristiansand, og professor ved Institutt for indremedisin, Universitetet i Bergen.

Forfatter har fylt ut ICMJE-skjemaet og oppgir ingen interessekonflikter.

\section{Litteratur}

1. Wikström AK, Stephansson O, Kieler $\mathrm{H}$ et al. Snus under graviditet är inget riskfritt alternativ till rökning. Läkartidningen 2011: 108: 1430 -3.

2. England LJ, Levine RJ, Mills JL et al. Adverse pregnancy outcomes in snuff users. Am J Obstet Gynecol 2003; 189: 939-43.

3. Wikström AK, Cnattingius S, Galanti MR et al. Effect of Swedish snuff (snus) on preterm birth. BJOG 2010; 117: 1005-10.

4. Wikström AK, Cnattingius S, Stephansson 0 Maternal use of Swedish snuff (snus) and risk of stillbirth. Epidemiology 2010; 21: 772 -8

5. Gunnerbeck A, Wikström AK, Bonamy AKE et al. Relationship of maternal snuff use and cigarette smoking with neonatal apnea. Pediatrics 2011 128: 503-9.

6. Clark SM, Nakad R. Pharmacotherapeutic management of nicotine dependence in pregnancy. Obstet Gynecol Clin North Am 2011; 38: 297-311.

7. Forinash AB, Pitlick JM, Clark K et al. Nicotine replacement therapy effect on pregnancy outcomes. Ann Pharmacother 2010; 44: 1817-21.

8. Coleman T, Chamberlain C, Cooper S et al. Efficacy and safety of nicotine replacement therapy for smoking cessation in pregnancy: systematic review and meta-analysis. Addiction 2011; 106: $52-61$.

Mottatt 20.2. 2012 og godkjent 8.3. 2012. Medisinsk redaktør Petter Gjersvik. 